\title{
Impacts of Adaptive Reuse of Heritage Buildings Converted to Small Hotels in Bangkok
}

\author{
Chotewit Pongsermpol, Prapatpong Upala
}

Faculty of Architecture, King Mongkut's Institute of Technology Ladkrabang (KMITL), Thailand

chotewit@hotmail.com

\begin{abstract}
Adaptive reuse (AR) is the process of reusing building to new purposes. In Bangkok, the popularity of AR turned to small hotels (AR-hotel) is increasing. There are more criteria for substantial renovation, business investment and valuing of heritage buildings but no concern to the community surrounding. This study was aimed to investigate community impacts occurred from AR-hotel projects. The key variables focused on four main issues - physical, economic, value and social issues. The results indicated that there were better physical improvements, livable area, more public social interaction whereas there was a little disturbance, and not much socialization of privacy.
\end{abstract}

Keywords: adaptive reuse; hotel; heritage building; community impacts;

eISSN 2398-4279 @ 2018. The Authors. Published for AMER ABRA cE-Bs by e-International Publishing House, Ltd., UK. This is an open access article under the CC BY-NC-ND license (http://creativecommons.org/licenses/bync-nd/4.0/). Peer-review under responsibility of AMER (Association of Malaysian Environment-Behaviour Researchers), ABRA (Association of Behavioural Researchers on Asians) and cE-Bs (Centre for EnvironmentBehaviour Studies), Faculty of Architecture, Planning \& Surveying, Universiti Teknologi MARA, Malaysia.

DOI: https://doi.org/10.21834/ajqol.v3i13.163 


\subsection{Introduction}

Adaptive Reuse (AR), a method of heritage building preservation, can rehabilitate historical buildings and area. We can keep the construction, façades, and ornaments, and renovate the interior as much as possible and adapt the inside of a building to a new use (Pongsermpol, 2009). This method is the only one architectural heritage conservation approach that addresses all three mains issues of sustainability development: the environment, economy, and society (Giddings, 2002). However, adaptive reuse (AR) can be controversial as there is sometimes a blurred line between renovation and adaptive reuse. It can be regarded as a compromise between historic preservation and demolition. Adaptive reuse is a process of reusing and building for a different purpose that can be either cumulative income or non-income for the building owner. Adaptive reuse patterns have been classified into eight groups according to usage pattern in the past and present (Pongsermpol, 2011) such as old houses or palaces converted into office buildings, museums, boutique hotels or restaurants as well as shops. For this research study, we focused on one kind of adaptive reuse buildings converted to Hotel Buildings (AR-hotels). There were several reasons why conversion of valuable old houses into AR-hotels was very popular in Bangkok: awareness of heritage conservation, enactment of Hotel Act-2008, information technology development, public transport network development and access to ASEAN Economic Community (AEC).

In the case of AR-hotel, there were several criteria for substantial renovation, business investment and evaluation of heritage building. For the topic of significant renovation, there were architectural and interior standards applicable to small hotel design such as four main distinct types of areas: guest room, public area, administration office and 'back-of-house' facility (Pickard, 2002). For the topic of business investment, there were five main issues in small hotel business operation: service design, operation, sales and marketing, finance and accounting as well as management (Suksawasdi, 2015). And for the topic of evaluation of heritage building, there were some criteria concerning the heritage value and authenticity such as cultural and socio-economic value regarding authenticity (WHC, 2015). Specifically, social impact on surrounding community has not been covered much in the literature even though it was a significant issue. For instance, the presence of an AR-HB-hotel in Tha Tien district in Bangkok has caused some conflict between the hotel manager and the neighboring residential community. As time passed, the hotel manager and staff were able to improve themselves and started to take part in some activities with the nearby community (Unnapirak, 2010). Most AR-hotel projects were always initiated without taking into account the surrounding community (Suksawasdi, 2016). Thus, the AR-hotels that we investigated and their business development might exert some impacts on their neighborhood. At this time, there still has been no particular study of social impacts, so we were interested in doing so. We aimed to investigate community impacts from AR-HB-hotel. The key variables focused on four main issues which were (1) environmental issue including issues of community surroundings and infrastructure system, (2) economic issue including issues of community development and investment opportunity, (3) social issue including issues of safety and social interaction, and (4) value issue which was variety of value assessment.

For the research scope, this research is a primary survey part of a comprehensive study on the topic of 'Changes and Impacts of AR-HB-hotels in Bangkok.' The target cases were 
50-year-old-or-over AR-HB-hotels and other small hotels of which capacity were not more than four rooms or not more than 20 guests all around Bangkok and their surrounding communities. As a pilot study, we chose to investigate three representatives of these AR-HB hotels with different kinds of surrounding communities; commercial, residential, and old waterfront community area.

Nomenclature

AR

AR-HB-hotel

Adaptive Reuse

Adaptive Reuse Heritage Building converted to the Hotel Building

\subsection{Literature Review}

This review of the literature focused on community impacts from gentrification, tourism and value perception as follows. Firstly, gentrification is a concept about the phenomenon of urbanization being a gradual process of spatial transformation of old buildings in the central urban area into new middle-class residential or commercial buildings (Loretta Lees, 2008). This phenomenon can be a powerful force that often rapidly transforms the physical, economic and social characteristics of an area (Rabiatul Adawiyah Abd Khalila, 2014). Regarding its benefits, gentrification can improve declining areas of a city, increase asset values, provide more revenue for local government, decrease vacant space ratio, cause less urban expansion into the suburb, and provide more social integration including public and community rehabilitation (Atkinson R., 2005). On the other hand, this can cause replacement of people through higher asset value and rent, less sentimental value than materialism, indignity, conflict in the community, uncertain change in asset value and loss of house supplying power. Moreover, it can lead to fewer available houses, lack of accommodation, replacement of commercial and industrial areas, change of local services, and loss of social diversity as well as original inhabitants (Atkinson R., 2005). Regarding neighborhood and change, gentrification is related to three issues, namely, (1) primacy of the neighborhood community; (2) diversified concepts of neighborhood: substantive nature, social ecology, cycle of equilibrium and disequilibrium, and social organization and assimilation; and (3) attention to race, ethnicity, and poverty (Miriam Zuk, 2015).

Secondly, tourism impact includes several key independent variables that influence the attitudes toward tourism (Samuel V. Lankford, 1994). Although tourism causes a positive economic outcome, it can exert negative impacts on the socio, cultural, economic, environmental and political development of the destination country (UNEP, 2003) depending on the way that it is managed. There are three issues of tourism impacts: the environment, the society, and the economy (Mason, 2016). The details of each type of impact can be found in a UNEP web document (UNEP, 2003).

Lastly, regarding heritage value approach, value types and authenticity in heritage assessment are aspects of communities' perception. There are two main types of value; cultural and socio-economic value, detailedly expressed as identity, artistry, rarity, functional, economic, educational, social, and political value (Jokilehto, 1998). Authenticity is still 
significant in valuing cultural heritage of which UNESCO uses as a criterion in their evaluation of World Heritage

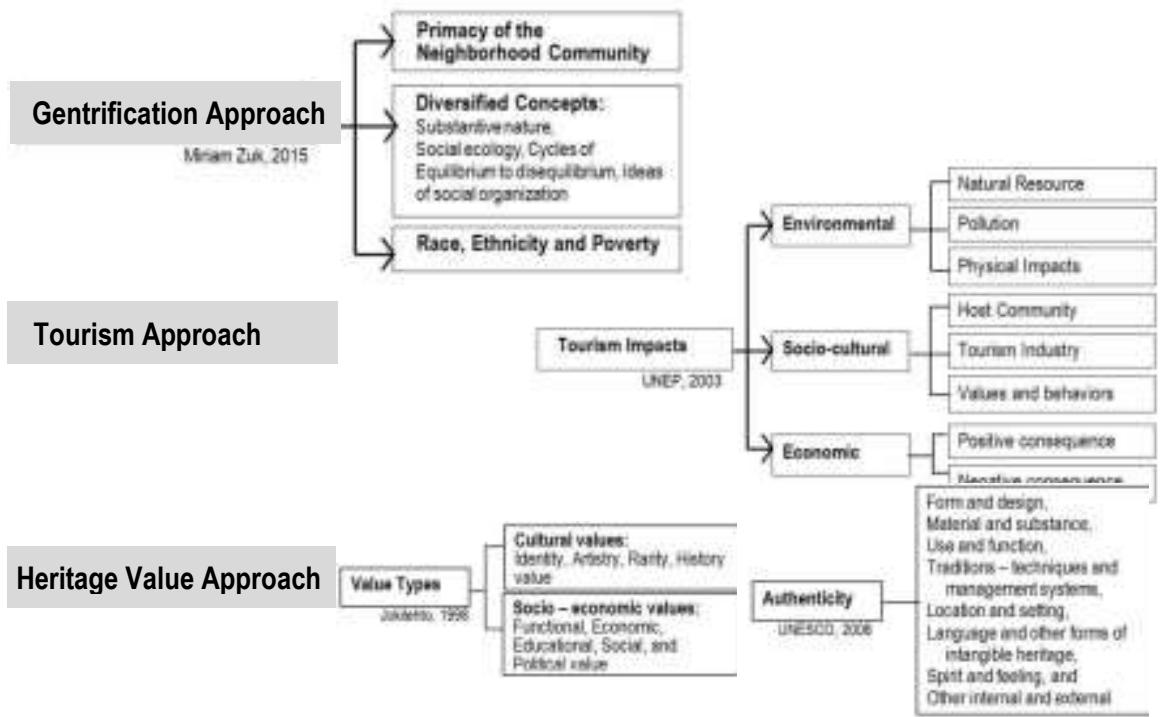

Fig. 1: Flow chart of Gentrification, Tourism, and Heritage Value Approach

Litnrature Reviaw

\begin{tabular}{|c|}
\hline 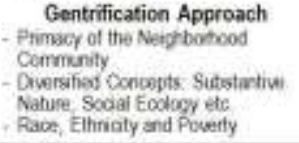 \\
\hline 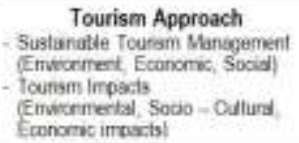 \\
\hline
\end{tabular}

\section{Heritage value approsch}

- Value Types

Bosently, Avtistry. Fabity. Functiond.

E,conorive, Educahiond, Social efe.)

- Authentioly

Foun $\&$ Desigh Malenti \&

Sutsiaron, Use \& Fundiun ete)

\section{Mathodology}

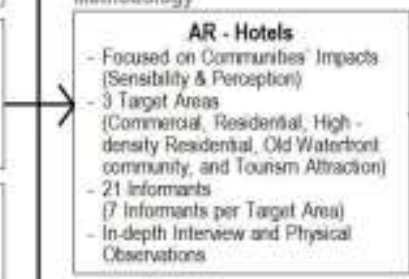

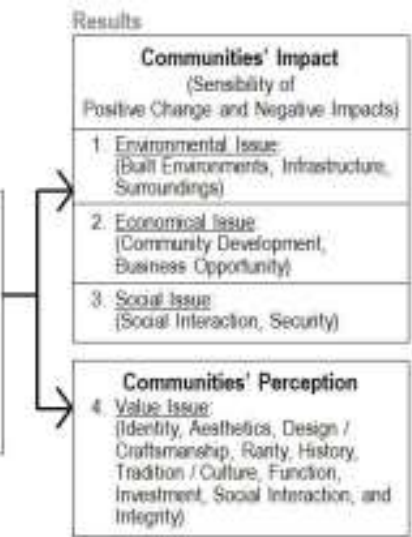

Fig. 2: Research framework shown relevant issues 
. In the past, authenticity was classified to be four issues: material, design, workmanship and setting (Jokilehto, 1998), but nowadays it has been categorized into eight-item groups: form and design, material and substance, use and function, traditions - techniques and management systems, location and setting, language and other forms of intangible heritage, spirit and feeling, and other internal and external factors (UNESCO, 2008). In this study, the focuses on communities' value perception were on the issue of identity, aesthetics, design, rarity, history, tradition, function, investment, social interaction, and integrity. An overview of our usage of these three approaches is illustrated in the flow chart below (See Fig.1).

Significant variables in this study are four dimensions of tourism impacts: environmental, socio-cultural, and economic impacts as well as heritage value. The research framework and central issues were feelings and perceptions of the communities on such impacts and value.

\subsection{Methodology}

\subsection{Target Area}

The target areas are located in Bangkok metropolis. There were three community types; (1) commercial, (2) residential area, and (3) old waterfront community area. All the target area locations are shown on the map of Bangkok Metropolis in Fig. 3. This research was focused on integrated community impact perception so that the AR-HB-hotel names would not be revealed in this article.

\subsection{Research Tools}

Being a qualitative research, the physical and surroundings data were collected from survey and observation while the perceptions of the communities on the impacts were gathered from in-depth interviews. Digital camera, sound recorder, and interview guideline paper were used as the tools for data collection.

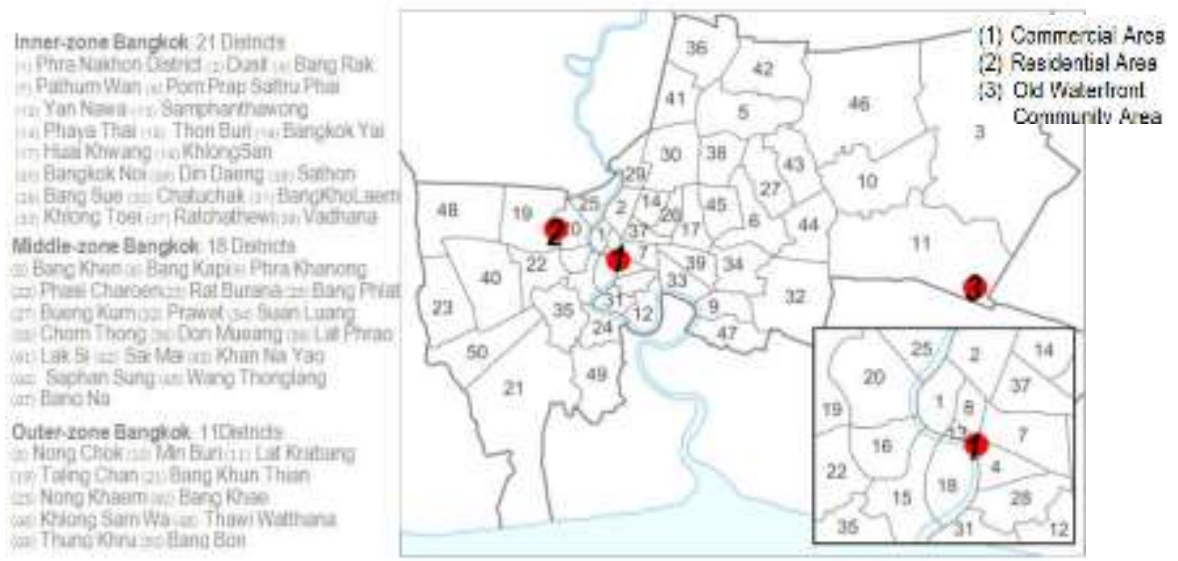

Fig. 3: A Map of Bangkok Metropolis with three locations of the target community area 


\subsection{Data Collection}

The qualitative survey for in-depth interview was focused on seven people per one casestudy area. Four main issues - sensibility of environmental, economic, and socio-cultural impacts and value perception - were collected from 21 informants who have been dwelling near the AR-HB Hotel for over ten years. The interview location around the hotels and primary site analysis are shown in the community maps (see Fig.4). The interview activity and atmosphere are shown in Fig. 5.
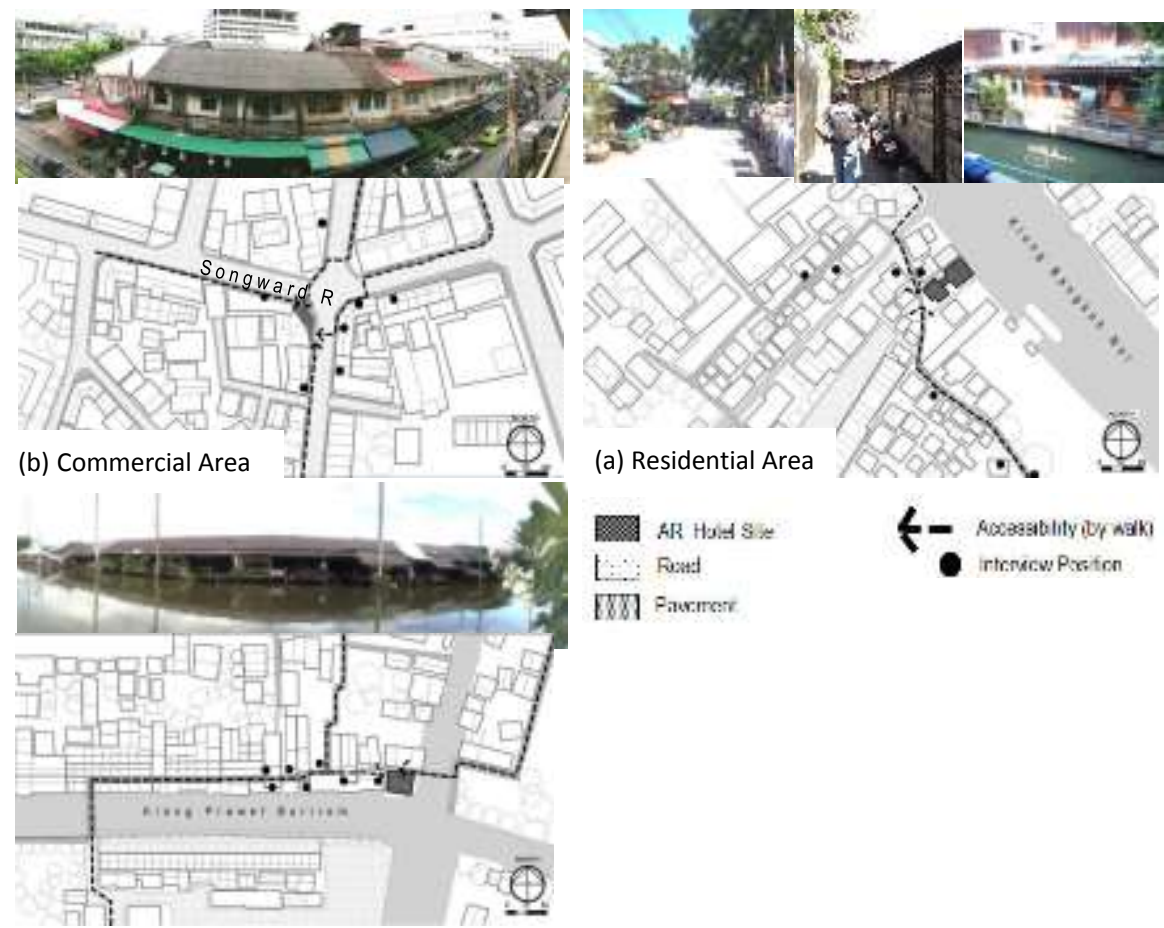

(c) Old Water Community Area

Fig. 4: Pictures of communities' map marked the interview location of three target areas
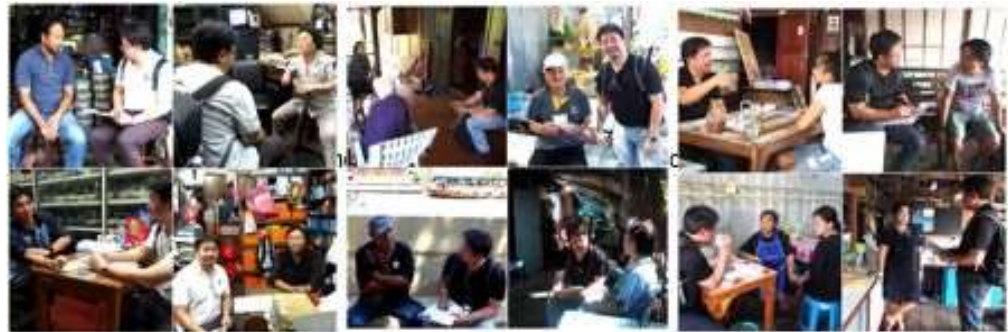

Fig. 5: Atmosphere, surroundings, and samples of interview activities for three target area 


\subsection{Results and Discussion}

The results are discussed as an overview of all three cases. Neither admiration nor criticism was intended towards the participants' personal comments. The results showed that the adaptive reuse projects truly affected the surrounding communities. The impacts on the communities were both positive and negative. The data collection period was from midNovember to mid-December 2016. There were 21 informers, ten females and eleven males, who were 21 to 94 years of age. Their careers were various such as student, housewife, employee, business owner, monger, caterer, freelance, and retiree. Educational level ranged from primary school to bachelor degree.

Table 1. Advantages and disadvantages to the communities from AR-HB-hotel projects

\begin{tabular}{|c|c|c|c|c|c|c|c|c|c|c|}
\hline \multirow{3}{*}{\multicolumn{2}{|c|}{ Van lasut }} & \multicolumn{9}{|c|}{ Sersibily of commulity resresertbives } \\
\hline & & \multicolumn{3}{|c|}{$\begin{array}{l}\text { Disadvartage } \\
\text { (Negche inpact) }\end{array}$} & \multicolumn{3}{|l|}{$\begin{array}{l}\text { Townal } \\
\text { Opinion }\end{array}$} & \multicolumn{3}{|l|}{$\begin{array}{c}\text { Advariage } \\
\text { IPosilve Chancei }\end{array}$} \\
\hline & & Cocmert & Free & Rate & Comment & Freq & Ratg & Comment & Fred & Reto \\
\hline \multirow[t]{4}{*}{1.} & $\begin{array}{l}\text { Envirenment } \\
\text { Bult } \\
\text { erwironont }\end{array}$ & $\begin{array}{l}\text { - Losa of use of shared } \\
\text { public space such as } \\
\text { public sar park. }\end{array}$ & 1 & 48 & $\begin{array}{l}\text { - No sflect on fhe } \\
\text { comminity image } \\
\text { - No coestent } \\
\text { - Ordinary }\end{array}$ & 5 & 238 & 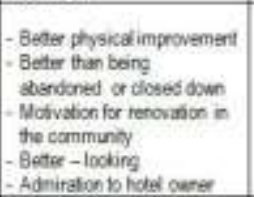 & is & 71,4 \\
\hline & Infrastruchee & (none) & $\checkmark$ & 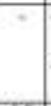 & $\begin{array}{l}\text { - Unrekated is public } \\
\text { eloctricity \& witer supply } \\
\text { - No eflect on } \\
\text { thoroughtire }\end{array}$ & 19 & 905 & $\begin{array}{l}\text { - More pubic fogt dong the } \\
\text { parasageway (by hotel owniss) }\end{array}$ & 2 & $\overline{95}$ \\
\hline & Sumandings & $\begin{array}{l}\text { - More moloricy des } \\
\text { - Sharng public car pani }\end{array}$ & 2 & 95 & - No eriect on tritic jam & 18 & Bist & $\begin{array}{l}\text { - Moen ifuminabon at noft } \\
\text { - Wates susply inprovernert }\end{array}$ & 1 & 48 \\
\hline & \multicolumn{2}{|l|}{ Total } & 3 & 4.7 & & 42 & 58.6 & & 18 & 28.6 \\
\hline \multirow[t]{3}{*}{2.} & $\begin{array}{l}\text { Ecosomic } \\
\text { Conmminity } \\
\text { Devolopment }\end{array}$ & $\begin{array}{l}\text { - Irappropnade for idertily } \\
\text { of community inage }\end{array}$ & 1 & 4.8 & $\begin{array}{l}\text { - Oedinsry, Inactive } \\
\text { - Not help becases of } \\
\text { different cliert group }\end{array}$ & 8 & 38.1 & $\begin{array}{l}\text { - Befler comnunity or burism } \\
\text { dovdapmont } \\
\text { - More comminities incione } \\
\text { tout not ruch }\end{array}$ & 12 & 571 \\
\hline & $\begin{array}{l}\text { Eusiness } \\
\text { Ocoortuney }\end{array}$ & (nonel & - & - & $\begin{array}{l}\text { - Wo lasa because of living } \\
\text { in a large family and not } \\
\text { being a house cuner. }\end{array}$ & 76 & 782 & 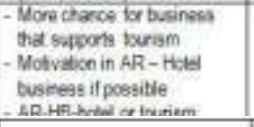 & 5 & 28 \\
\hline & \multicolumn{2}{|l|}{ Tad } & 1 & 24 & & 24 & 57.1 & & 17 & 405 \\
\hline \multirow[t]{4}{*}{ 3. } & $\begin{array}{l}\text { Social } \\
\text { Social } \\
\text { interaction }\end{array}$ & $\begin{array}{l}\text { - More crouded } \\
\text { - A fittle disturbarce is } \\
\text { privacy but beconing } \\
\text { tamiliar ag seme passed }\end{array}$ & 2 & 95 & $\begin{array}{l}\text { - No socialization } \\
\text { - Not crowed } \\
\text { - No prodiam } \\
\text { - No distubiarce }\end{array}$ & 8 & 38.1 & 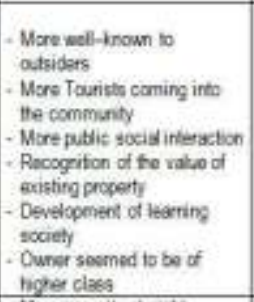 & t1 & 524 \\
\hline & Secuenty & (ione) & + & + & - Mo sbect & 15 & 857 & - More security a niph & 3 & 14.3 \\
\hline & \multirow{2}{*}{\multicolumn{2}{|c|}{ Tod }} & 2 & 4.8 & & 26 & 515 & & 14 & 33.3 \\
\hline & & & 6 & 4.1 & & 52 & 626 & & 89 & $\sqrt{33.3}$ \\
\hline
\end{tabular}

The positive and negative impacts (see the details in Table 1) on the communities were of four main issues: communities' perceptions of (1) environmental, (2) economical, and (3) social issues. Overall, all of the informants mostly expressed a neutral opinion (62.6\%) 
followed by advantage (33.3\%) and disadvantage (4.1\%). Value issues according to the community perceptions are shown in Table 2.

Firstly, the environmental issue: more than a quarter of the informants felt positive physical changes (28.6\%). Some informants (4.7\%) felt the negative aspects. However, most people $(66.6 \%)$ expressed a neutral opinion. Secondly, the economic issue: $40.5 \%$ expressed positive opinions on the economic aspect. Very few (2.4\%) expressed negative, but most (57.1\%) expressed a neutral opinion.

Thirdly, the social issue: most informants $(61.9 \%)$ also expressed a neutral opinion. One-third expressed positive opinions, and only $4.8 \%$ expressed negative opinions.

Lastly, the value issue: about half of the informants (57.6\%) were able to realize the values of their community while approximately one - third $(29.5 \%)$ of them felt neutral and a few of them $(6.7 \%)$ had no idea how to assess the value of their community whereas very few $(6.2 \%)$ had a negative perception.

Table 2. Value perception of AR - Hotel projects in the view of the neighborhood community

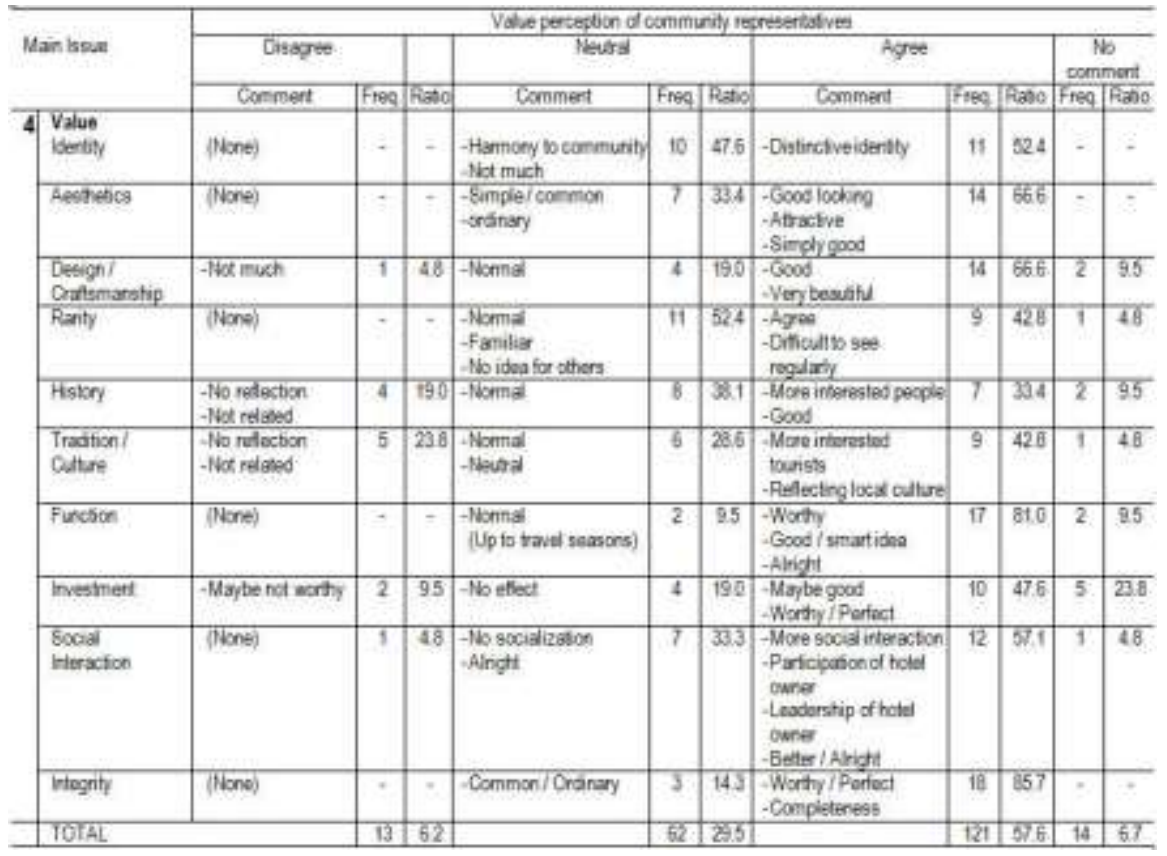

Overall, these three cases showed a trend of positive changes compared to the conflicts that happened in some other areas mentioned in the introduction section. We found that these AR-HB-hotel projects did not exert negative impacts to the communities' infrastructure or business opportunity. Although there were not many negative impacts, we still had to consider each case in on a case-by-case basisFor the environmental impact, most people were aware that AR-HB hotels were able to make the communities physically better and 
livelier. The hotels created motivation to renovate their own places but did not have much effect on the communities' infrastructure -

Table 2. Value perception of AR - Hotel projects in the view of the neighborhood community and surrounding. Regarding the social impact issue, there were more tourists and more public social interaction. Most expressed a neutral opinion and stated that they did not have anything much to do with the hotels. They lived by themselves and did not socialize with the high-level hotel owner. Regarding the economic impact, there should have been significant advantages for the communities, but some thought that there were not, probably because their thoughts were influenced by factors such as existing business, private behavior, and house ownership. An interesting opinion was that the hotel business might be another alternative for the future of the community. Furthermore, some conflicts had occurred at the beginning of the projects but were resolved afterward.

Lastly, regarding the value perception, slightly more than half of the informants realized the different types of values especially the function, integrity, aesthetics and design values. Some people felt that they were already familiar with this style of building, so they expressed neutrality for their ideas of identity and rarity values. Approximately, a quarter of the informants considered that AR-HB-hotels did not reflect the history and tradition value of their community. More than half responded neutrally or gave no comments. Around half of them perceived that the investment value was a little higher and the social value was a little lower.

\subsection{Conclusion}

As a qualitative study, these results cannot be fully generalized to the cases of all other ARHB-hotel projects with different surrounding communities, but they can make interested people realize the positive changes and negative impacts that have occurred from this kind of projects.

For positive changes, AR-HB-hotels were able to improve the physical environment, livable area, and motivation for renovation in the community. They did not affect the communities' infrastructure and surrounding much. Moreover, they brought in more visitors into the communities and created more public social interaction including more opportunities for businesses that supported tourism. Anyway, more than half of the people did not pay attention to the hotels much. This isolation may imply that there was not much socialization between the hotel owners and the communities that varied from case to case.

For value perceptions, they were not always clear and were difficult to measure. We found that slightly more than half of the informants realized different types of values, especially the function and integrity values as well as the aesthetic and design values. For further study, various types of value should be advantageously grouped into easier-to-recognize classes.

\section{Acknowledgement}

I would like to express my thanks to my dissertation advisor, Dr. Prapatpong Upala, and Mr. Pratana Kangsadl for his invaluable help and constant encouragement. Also, I am grateful to 
my partner, Pum, Mana, Tick, and Wut for data collection. Lastly, I would like to thank the faculty of Architecture, KMITL and all of my friends in the multi-disciplinary program.

\section{References}

Bernard M. Feiden and Jukka Jokilehto. (1998). Management Guidelines for World Cultural Heritage Sites. Rome: OGRARO.

Atkinson R., B. G. (2005). Gentrification in a Global Context. The new urban colonialism. New York, U.S.A.: Routledge.

Bob Giddings, B. H. (2002). Environment, economy, and society: fitting them together into sustainable development. Sustainable Development, 187-196

Chantong, P. (2015, August 14). Policy, Basic Structure Development of Transportation in Thailand. Bangkok: The Office of Transport and Traffic Policy and Planning, Ministry of Transport.

Loretta Lees, T. S. (2008). Gentrification. New York, U.S.A.: Routledge: Taylor and Francis Group.

Mason, P. (2016). Tourism Impacts, Planning and Management (third ed.). Oxford, United Kingdom: Routledge.

Miriam Zuk, A. H.-S. (2015). Gentrification, Displacement and the Role Gentrification,. California: University of California, Berkeley.

Pickard, Q. (2002). The Architects' Handbook. Oxford, United Kingdom: Blackwell Publishing.

Pongsermpol, C. (2009). Adaptive-Reuse Policy Improvement in Urban Conservation for Thai Context. AAHM2009 2nd Asian Academy for Heritage Management Conference on Urban Heritage and Tourism: Challenges and Opportunities (pp. 334-336). Marcao SAR, China: Institute for Tourism Studies.

Pongsermpol, C. (2011). Participants' Attitudes for Adaptive Reuse in Heritage Buildings for Thai Context. ICOMOS Thailand International Conference 2011, (pp. 217-227). Phuket, Thailand.

Rabiatul Adawiyah Abd Khalila, F. J. (2014). The Impact of New-build Gentrification in Iskandar Malaysia: A case study of Nusajaya. ASEAN-Turkey ASLI (Annual Serial Landmark International) Conference on Quality of Life 2014, ABRA International Conference on Quality of Life, AQoL2014, 26-28 December 2014 (p. 495).

Istanbul, Turkey: ScienceDirect.

Regulations, M. (2008, May 14). Determination the types and guidelines in hotel business. Bangkok: Ministry of the Interior.

Stovel, H. (2002). Approaches to Managing Urban Transformation for Historic Cities. The Conservation of Urban Heritage: Macao Vision (pp. 103-120). Macao: Macao Vision.

Suksawasdi, A. (2015). Small hotel business operation. Lifestyle Workshop for Small Hotel: Practical Scence for Efficient Result. Grand Hyatt Erawan Hotel, Bangkok. 
Pongsermpol, C., \& Upala, P. / Asian Journal of Quality of Life (AjQoL), 3(13) Sep/ Oct 2018 (p.69-79)

Swarbrooks, J. (1998). Sustainable tourism management. New York, U.S.A.: CABI Publishing.

Thammabut, P. (2006). The principle of sustainable tourism. Bangkok: Institute for the development of tourism to environmental conservation. University of Srinakarintarawirot .

UNEP, U. N. (2003). Impacts of Tourism. United Nations Environment Programme. Retrieved December 06, 2016, http://www.unep.org/resourceefficiency/Business/SectoralActivities/Tourism/

FactsandFiguresaboutTourism/ImpactsofTourism/tabid/78774/Default.aspx

UNESCO. (2005). Operational Guidelines for the Implementation of the World Heritage Convention. p.22: World Heritage Center.

Unnapirak, K. (2010, February 17). Arun Residence Building. (C. Pongsermpol, Interviewer)

WHC, U. (2015). Operational Guidelines for the Implementation of the World Heritage Convention. Paris: UNESCO World Heritage Centre. 